\title{
Analysis of the expression from Rhizobium meliloti fix-promoters in other Rhizobium backgrounds
}

\author{
Angel Cebolla, Francisco Ruiz-Berraquero and Antonio J. Palomares
}

Author for correspondence: Antonio J. Palomares. Tel: +34 545567 66. Fax: +34 54628162.

Departamento de Microbiología y

Parasitología, Facultad de Farmacia, Universidad de Sevilla, clo Profesor Garcla Gonzalez s/n, 41012 Sevilla, Spain

\begin{abstract}
Using translational fusions to lacZ, we have measured expression from the promoters of Rhizobium meliloti regulatory genes, nifA and fix $K$, and structural genes, nifH and fixA, in other fast-growing rhizobia whose nitrogen fixation regulation is less known. Neither nifA nor fixK promoters were activated under both free-living microaerobic and symbiotic conditions, except in $R$. tropici, where clear symbiotic activation of either nifA or fixK expression could be observed. Both nifH and fixA promoters showed strong heterologous activation during symbiosis and weak activation under free-living nitrogen starvation conditions. Only when the nifH promoter was in $R$. tropici and $R$. leguminosarum bv. phaseoli, was clear induction observed in the microaerobic free-living state. Deletion analysis of these promoters suggested that a NifA binding site (UAS) was needed for full heterologous activation of nifHp, either in microaerobiosis or symbiosis. In contrast, the UAS region seemed to be unnecessary for fixA activation. However, a region containing a potential integration host factor (IHF) binding site was observed to be needed for complete heterologous symbiotic induction from fixAp. The moderate induction observed in nitrogen-free medium only required the $\sigma^{54}$ holoenzyme recognition sequence; this may be indicative of the existence of non-specific activation by NtrC-like proteins. Our results suggest possible common and different features in the control mechanisms of the nitrogen fixation gene expression among Rhizobium species.
\end{abstract}

Keywords: Rbizobium meliloti, promoters, nitrogen fixation genes, gene expression, heterologous expression

\section{INTRODUCTION}

Rbizobium bacteria infect legume plant roots and cause cortical cell division leading to the formation of nitrogenfixing nodules. The root nodule provides the appropriate biochemical environment for the conversion of atmospheric dinitrogen to ammonia.

The ability of rhizobia to induce $\mathrm{Fix}^{+}$nitrogen nodules requires the specific expression of certain bacterial genes. The regulation of the expression of $R$. meliloti genes needed for symbiotic nitrogen fixation has been the subject of intense study. As a consequence, it is known that a two-component regulatory system, fix $L J$ (David $e t$ al., 1988), in response to low oxygen tension activates

Abbreviations: IHF, integration host factor; UAS, upstream activator sequence. expression of the regulators nif $A$ and fixK (Batut $e t$ al., 1989), which in turn induce the expression of structural genes needed for nitrogen fixation.

Although expression of both fix $K$ and nif $A$ is under direct control of Fix J, sequence analysis of the $R$. meliloti fixK and nif $A$ promoters did not reveal any extensive block of identical nucleotides. Nevertheless, it seems likely that there is a common sequence motif in the -54 to -39 region of both promoters that is required for fix $L J$ dependent microaerobic induction (Agron et al., 1992; Waelkens et al., 1992). Since fixK expression is dependent on RpoD (Batut et al., 1991), it is then expected that nif $A p$ may also be recognized by RpoD $\left(\sigma^{70}\right)$.

The regulation of symbiotic nitrogen-fixation gene expression in Rbizobium species other than $R$. meliloti is poorly known. As an exception, Colonna-Romano et al. (1990) observed heterologous microaerobic induction of a 
R. meliloti fix $N-l a c Z$ fusion in $R$. leguminosarum bv. viciae, and identified its activator as the product of an ORF that is homologous to R. meliloti fixK. However, attempts to find a fixJ-like gene in $R$. leguminosarum bv, viciae were unsuccessful. Symbiotic nitrogen-fixing bacteria related to Rhizobium and whose fix-regulation is also being elucidated, Bradyrbizobium japonicum (Anthamatten et al., 1992; Anthamatten \& Hennecke, 1991) and Azorbizoinium caulinodans (Kaminski \& Elmerich, 1991; Kaminski et al., 1991), share some common regulatory elements with those of $\mathrm{R}$. meliloti but differ in multiple aspects with regard to their regulatory models. Thus, in $A$. caulinodans, FixLJ activate $f x K$ expression in microaerobiosis which in turn induces NifA expression (Kaminski \& Elmerich, 1991; Kaminski et al., 1991). A. caulinodans fixKp shows homology with that of R. meliloti, but NifA expression is activated via FixK, as indicated by the fact that $A$. caulinodans nif $A p$ has an anaerobox found in FnrNdependent promoters (Ratet $e t$ al., 1989). In B. japonicum, NifA activity is regulated by oxygen (Fisher $e t$ al., 1988). nif $A$ is expressed from the fix Rnif $A$ operon and under microaerobiosis, NifA positively regulates nif and fix gene expression (Fisher \& Hennecke, 1987). The B. japonicum fix Rnif $A$ operon has a $\mathrm{RpoN}$ consensus sequence promoter (Thöny et al., 1987), differing from that of $R$. meliloti, which is expected to be RpoD-dependent (Batut $e t$ al., 1991). fixLJ and fixK are present in B. japonicum, but fix $L J$ are not involved in nif $A$ expression (Anthamatten $e t$ al., 1992; Anthamatten \& Hennecke, 1991).

Many of the structural genes needed for $R$. meliloti nitrogen fixation are clustered in two operons: nifHDKE, which encodes the structural genes of the nitrogenase complex (Ruvkun et al., 1982); and fix $A B C X$, encoding as yet undetermined functions essential for nitrogen fixation (Corbin et al., 1983). The expression of each operon requires both the $\operatorname{rpoN}(n \operatorname{tr} A)$ product, which is the $\sigma^{54}$ factor (Ronson et al., 1987), and the positive regulatory protein, NifA (Szeto et al., 1984). The activity of NifA is regulated post-translationally by oxygen sensitivity of the protein (Fisher et al., 1988). The R. meliloti promoters activated by NifA, nif $\mathrm{H} p$ and $f i x, A p$, have the conserved $-24(\mathrm{GG}) /-12(\mathrm{GC})$ consensus sequence of RpoN (Better et al., 1983; Kustu et al., 1989; Thöny \& Hennecke, 1989), the putative NifA-binding site (upstream activator sequence, UAS; Buck et al., 1988) and a potential site where an integration host factor may bind (IHF; Santero et al., 1989; Hoover et al., 1990) which stimulates NifA-mediated activation of nif transcription in Klebsiella pneumoniae. Both promoters share extensive sequence homology for more than $160 \mathrm{bp}$ upstream of the RNA start point. However, fix $A p$ contains a 9 bp insertion at position -27 and significant variation is apparent in the region between the transcriptional and translational start sites (Better et al., 1983). These divergences seem to lead to differences in expression in Escherichia coli by either the Klebsiella pneumoniae NifA or the E. coli $\mathrm{NtrC}$ (nifHp is activated but not fix Ap, Better et al., 1985), and in R. meliloti under specific physiological conditions (Birkenhead et al., 1990; Ditta et al., 1987). Details of this nif/fix regulation in other species of
Rbizobium are poorly understood. To test for evidence of common regulatory elements that control activation of $R$. meliloti nif $A p$, fixKp, nifH $\mathrm{H}$ and $f i x A p$ in other fastgrowing Rbizobium species, we have studied heterologous expression from those promoters under physiological conditions that allow their activation in R. meliloti.

\section{METHODS}

Bacterial strains and plasmids. Bacterial strains and plasmids used in this study are described in Table 1.

Media. E. coli was grown in $\mathrm{LB}\left(1^{-1}: 10 \mathrm{~g}\right.$ tryptone, $5 \mathrm{~g}$ yeast extract and $10 \mathrm{~g} \mathrm{NaCl})$ and all rhizobia in TY $\left(1^{-1}: 5 \mathrm{~g}\right.$ tryptone, $3 \mathrm{~g}$ yeast extract, $0.84 \mathrm{~g} \mathrm{CaCl}_{2}$ ). Nitrogen-free medium contained $7.4 \mathrm{mM} \mathrm{KH}_{2} \mathrm{PO}_{4}, 5.8 \mathrm{mM} \mathrm{K}_{2} \mathrm{HPO}_{4}, 2.5 \mathrm{mM} \mathrm{MgSO}_{4}$, $0.6 \mathrm{mM} \mathrm{CaCl} 2$ and $10 \mathrm{mM}$ sodium succinate. Tetracycline was used at $10 \mathrm{mg} \mathrm{l}^{-1}$, kanamycin at $20 \mathrm{mg} \mathrm{l}^{-1}$ and nalidixic acid at $10 \mathrm{mg} \mathrm{l}^{-1}$. Nutritive nitrogen-free solution for irrigating plant tests had the following components $\left(\mathrm{mg} \mathrm{l}^{-1}\right): \mathrm{CaSO}_{4}, 200$; $\mathrm{KH}_{2} \mathrm{PO}_{4}, 200 ; \mathrm{KCl}, 500 ; \mathrm{MgSO}_{4}, 200 ; \mathrm{H}_{3} \mathrm{BO}_{4}, 0 \cdot 1$; $\mathrm{ZnSO}_{4} .7 \mathrm{H}_{2} \mathrm{O}, 1 ; \mathrm{CuSO}_{4}, 0.5 ; \mathrm{MnCl}_{2} .4 \mathrm{H}_{2} \mathrm{O}, 0.5 ; \mathrm{Na}_{2} \mathrm{MoO}_{4}$. $2 \mathrm{H}_{2} \mathrm{O}, 0 \cdot 1$; ferric-sodium EDTA, 0.93 .

Matings. Plasmids were transferred into Rhizobium strains with helper plasmid pRK2013 by a triparental conjugation technique (Ditta et al., 1985). Transconjugants were selected in TY solid media supplemented with tetracycline and nalidixic acid.

Free-living assays. For free-living gene expression quantifications, saturated cultures were diluted with fresh medium and grown overnight under aerobic or microaerobic conditions at $29^{\circ} \mathrm{C}$ to an $A_{600}$ between 0.3 and 0.7 . For aerobic conditions, $5 \mathrm{ml}$ cultures were aerated by rotary shaker at 180 r.p.m. Microaerobic conditions were achieved as described by Ditta $e t$ al. (1987), exposing $2 \mathrm{ml}$ cultures to $1 \%$ oxygen $/ 99 \%$ nitrogen in $50 \mathrm{ml}$ stoppered flasks. For nitrogen-limiting conditions, exponential-phase cultures in TY medium were washed twice and resuspended in nitrogen-free medium containing succinate as the carbon source. $\beta$-Galactosidase activity was determined as previously described by Miller (1972). Specific activities are means of at least two measurements made on independent cultures.

Symbiotic assays. Alfalfa and clover seeds were surfacesterilized by immersion in $96 \%$ ethanol for $1 \mathrm{~min}$, washed with water and then incubated in $1 \% \mathrm{HgCl}_{2}$ solution in $10 \%(\mathrm{v} / \mathrm{v})$ ethanol/water for $3 \mathrm{~min}$. After washing 8-10 times in sterile water, seeds were placed on $0.8 \%$ agar plates and incubated at $29^{\circ} \mathrm{C}$. About $6-10$ germinated seeds were selected and placed in jars containing vermiculite and irrigated with nitrogen-free medium. Bean, soybean and pea seeds were sterilized by washing with water, immersion in $96 \%$ ethanol for 3-5 min, washing once with water, immersion in $12 \%$ sodium hypochloride for 5-15 min and washing at least 10 times with sterile water. Subsequent steps were identical to those described above for alfalfa and clover, but only one or two seeds were placed in each jar. Inoculations were performed as follows: alfalfa with $R$. meliloti, clover with Rbizobium leguminosarum bv. trifolii, pea with $R$. leguminosarum bv. viciae, bean with $R$. tropici and $R$. leguminosarum bv. phaseoli, and Phaseolus aureus with Rhirobium $\mathrm{sp}$. NGR234.

Bacteroids were isolated from 1-5 g of nodules picked from duplicate groups of plants grown for 4-5 weeks. Nodules were crushed, their bacteroids purified by differential centrifugation and $\beta$-galactosidase activity of bacteroids was determined as previously described by Better $e t$ al. (1985). Data are the average of at least two independent assays. To estimate plasmid stability 
Table 1. Bacterial strains and plasmids used in this study

\begin{tabular}{|c|c|c|}
\hline Strain/plasmid & Description & Reference \\
\hline \multicolumn{3}{|l|}{ Bacteria } \\
\hline E. coli HB101 & $\mathrm{F}^{-}$bsdS bdsM pro leu thi gal lac $Y \operatorname{rec} A \mathrm{Str}^{\mathrm{r}}$ & $\begin{array}{l}\text { Boyer \& Roulland-Dussoix } \\
\text { (1969) }\end{array}$ \\
\hline R. meliloti $102 \mathrm{~F} 34$ & Wild-type, $\mathrm{Nal}^{\mathrm{r}} \mathrm{Nod}^{+} \mathrm{Fix}^{+}$on alfalfa & Better et al. (1983) \\
\hline $\begin{array}{l}\text { R. leguminosarum bv. viciae } \\
300\end{array}$ & Wild-type, $\mathrm{Nal}^{r} \mathrm{Nod}^{+} \mathrm{Fix}^{+}$on pea & Johnston \& Beringer (1975) \\
\hline $\begin{array}{l}\text { R. leguminosarum bv. trifolii } \\
\text { RS } 800\end{array}$ & $\begin{array}{l}\text { Wild-type, } \mathrm{Nal}^{r} \mathrm{Nod}^{+} \mathrm{Fix}^{+} \text {on white and } \\
\text { subterraneum clover }\end{array}$ & Megías et al. (1989) \\
\hline $\begin{array}{l}\text { R. leguminosarum bv. phaseoli } \\
8002\end{array}$ & Wild-type, $\mathrm{Nal}^{\mathrm{r}} \mathrm{Nod}^{+} \mathrm{Fix}^{+}$on bean & Lamb et al. (1982) \\
\hline R. tropici CIAT899 & $\begin{array}{l}\text { Wild-type, } \mathrm{Nal}^{r} \mathrm{Nod}^{+} \mathrm{Fix}^{+} \text {on bean and } \\
\text { leucaena }\end{array}$ & $\begin{array}{l}\text { Martinez-Romero et al. } \\
\text { (1991) }\end{array}$ \\
\hline R. fredii $\mathrm{HH} 003$ & Wild-type, $\mathrm{Nal}^{\mathrm{r}} \mathrm{Nod}^{+} \mathrm{Fix}^{+}$on soybean & Dowdle \& Bohlool (1985) \\
\hline Rhizobium sp. NGR234 & $\begin{array}{l}\text { Wild-type, } \mathrm{Nal}^{\mathrm{r}} \mathrm{Nod}^{+} \mathrm{Fix}^{+} \text {on a broad } \\
\text { range of legumes, i.e. leucaena, soybean, } \\
\text { etc. }\end{array}$ & Trinick $(1980)$ \\
\hline \multicolumn{3}{|c|}{ 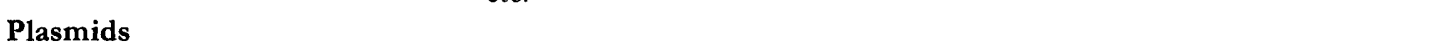 } \\
\hline pRK2013 & $\mathrm{Km}^{\mathrm{r}}$ tra ColE1 & Ditta et al. (1980) \\
\hline $\mathrm{pCHK} 57$ & $\mathrm{Tc}^{\mathrm{r}}$, pGD926 derivative $\mathrm{Rm}$ nif $A p::$ lac $Z$ & Ditta et al. (1987) \\
\hline pJJ5 & $T c^{\mathrm{r}}, \mathrm{pIJ} 363$ derivative $\mathrm{Rm}$ fix $K p::$ lac $Z$ & Batut et al. (1989) \\
\hline pMB210 & $\mathrm{Tc}^{\mathrm{r}}$, pGD926 derivative $\mathrm{Rm}$ nifH $\mathrm{H}:$ : lac $\mathrm{Z}$ & Better et al. (1985) \\
\hline pMB211 & $\mathrm{Tc}^{\mathrm{r}}$, pGD926 derivative $\mathrm{Rm}$ fix $A p$ : : lac $Z$ & Better et al. (1985) \\
\hline \multicolumn{3}{|l|}{$\begin{array}{l}\text { Promoter deletion } \\
\text { plasmids }\end{array}$} \\
\hline pMB1164 & As pMB210 but with $175 \mathrm{bp}$ of nifH ${ }^{*}$ & \\
\hline pMB1136 & As pMB210 but with $150 \mathrm{bp}$ of nif $\mathrm{Hp}$ & \\
\hline pMB1124 & As pMB210 but with 135 bp of nifHp & \\
\hline pMB1246 & As pMB210 but with 95 bp of nifHp & \\
\hline pMB1156 & As pMB210 but with 35 bp of nif Hp & \\
\hline pMB1097 & As pMB210 but with 10 bp of nifHp & \\
\hline pMB1107 & As pMB210 but with $-37 \mathrm{bp}$ of nif $\mathrm{Hp}$ & Better et al. (1985) \\
\hline pMB2346 & As pMB211 but with $178 \mathrm{bp}$ of $f i x A p$ & \\
\hline pMB2303 & As pMB211 but with 168 bp of $f \times A p$ & \\
\hline pMB2272 & As pMB211 but with 88 bp of $f i x A p$ & \\
\hline pMB2284 & As pMB211 but with 73 bp of $f x A p$ & \\
\hline pMB2363 & As pMB211 but with $33 \mathrm{bp}$ of $f x A p$ & \\
\hline pMB2256 & As pMB211 but with $3 \mathrm{bp}$ of $f x A p$ & \\
\hline
\end{tabular}

* Number of base pairs upstream of the transcription initiation point.

in nodules, the percentage of $\mathrm{Tc}^{\mathrm{r}}$ cells isolated from nodules was measured in eight independent experiments testing 100 colonies each time. Permanence of the plasmids ranged from 60 to $98 \%$.

\section{RESULTS}

\section{Expression of nifA and fixK in heterologous Rhizobium backgrounds}

Similar features seem to regulate expression from either the R. meliloti nif $A$ (Virts et al., 1988) and fixK promoters (Batut et al., 1989; Waelkens et al., 1992) not only in both free-living cells exposed to low oxygen but also in bacteroids existing in the environment of alfalfa roots. We used in vitro microaerobiosis as a primary model system to test if there are regulatory elements in other Rbizobium backgrounds that activate both promoters. $\beta$-Galactosidase activities from $R$. meliloti $102 \mathrm{~F} 34$ bearing nif $A p$ : : lac $Z$ or fix $K p:$ : lac $Z$ increased considerably under microaerobic conditions (Table 2). Similar results were obtained using other strains of R. meliloti in the assay (data not shown). However, under the same experimental conditions, none of the other species could induce expression substantially. We tested different oxygen concentrations $(0,0 \cdot 5,1,2,4$ and $20 \%$ ) to attempt to activate $\mathrm{R}$. meliloti nif $A p$ in $\mathrm{R}$. tropici and $\mathrm{R}$. leguminosarum bv. phaseoli, but no induction of $\beta$-galactosidase activity was observed (data not shown). It was noticeable that the background levels of homologous expression from both nif $A p$ and fixKp were considerably higher than those of the heterologous backgrounds. 
Table 2. $\beta$-Galactosidase expression from $R$. meliloti nifAp and fixKp in other heterologous Rhizobium spp.

Data are the mean of at least two independent assays $\pm \mathrm{sD} .+\mathrm{N}+\mathrm{O}$, Aerobic cultures in $\mathrm{TY}$ medium; $-\mathrm{N}+\mathrm{O}$, aerobic cultures in nitrogen-free medium; $+\mathrm{N}-\mathrm{O}$, microaerobic cultures in TY medium. NT, Not tested.

\begin{tabular}{|c|c|c|c|c|c|c|c|c|}
\hline \multirow[t]{3}{*}{ Species } & \multicolumn{8}{|c|}{$\beta$-Galactosidase expression (Miller Units) } \\
\hline & \multicolumn{4}{|c|}{ nif $A p:: \operatorname{lac} Z$} & \multicolumn{4}{|c|}{$f i x K p:: \operatorname{lac} Z$} \\
\hline & $+\mathbf{N}+\mathbf{O}$ & $-\mathbf{N}+\mathbf{O}$ & $+\mathbf{N}-\mathbf{O}$ & Symbiotic & $+\mathbf{N}+\mathbf{O}$ & $-\mathbf{N}+\mathbf{O}$ & $+\mathbf{N}-\mathbf{O}$ & Symbiotic \\
\hline R. meliloti & $119 \pm 34$ & $501 \pm 300$ & $1430 \pm 194$ & $1400 \pm 300$ & $221 \pm 89$ & $386 \pm 159$ & $1680 \pm 318$ & $1610 \pm 370$ \\
\hline R. tropici & $39 \pm 6$ & $538 \pm 209$ & $57 \pm 8$ & $1360 \pm 322$ & $15 \pm 7$ & $12 \pm 6$ & $10 \pm 4$ & $1690 \pm 220$ \\
\hline R. leguminosarum bv. phaseali & $36 \pm 3$ & $328 \pm 179$ & $50 \pm 4$ & $18 \pm 2$ & $11 \pm 6$ & $14 \pm 10$ & $16 \pm 9$ & NT \\
\hline R. leguminosarum bv. trifolii & $48 \pm 3$ & $118 \pm 30$ & $46 \pm 2$ & $11 \pm 4$ & $25 \pm 10$ & $32 \pm 2$ & $20 \pm 11$ & $\mathrm{NT}$ \\
\hline R. leguminosarum bv. viciae & $24 \pm 4$ & $318 \pm 8$ & $25 \pm 3$ & $10 \pm 4$ & $12 \pm 4$ & $10 \pm 4$ & $17 \pm 3$ & NT \\
\hline R. sp. NGR234 & $66 \pm 8$ & $839 \pm 17$ & $50 \pm 6$ & $17 \pm 1$ & $10 \pm 2$ & $10 \pm 3$ & $13 \pm 3$ & $\mathrm{NT}$ \\
\hline R. fredii & $44 \pm 2$ & $428 \pm 90$ & $34 \pm 3$ & $30 \pm 11$ & $14 \pm 5$ & $27 \pm 4$ & $59 \pm 1$ & $5 \pm 2$ \\
\hline
\end{tabular}

Ditta et al. (1987) reported that aerobic induction of nif $A$ expression could also occur during nitrogen starvation in R. meliloti. Under these conditions, a significant increase in expression from nif $A p$ was observed in every Rbizobium studied (Table 2 ). High variation in the levels of induction was observed. Relative to the basal level of $\beta$-galactosidase seen for pCHK57 (nif $A p$ : : lac Z) in TY medium, there was a 14-fold increase in $R$. tropici and a 3 -fold increase in $R$. leguminosarum bv. trifolii. In contrast, bacteria in nitrogenfree medium failed to activate transcription from the $R$. meliloti fix $K$ promoter. In addition, significantly higher heterologous nif $A p$ : : lac $Z$ expression was not observed when microaerobic and nitrogen starvation conditions were combined; instead, expression was slightly repressed in most of the cases (data not shown). In contrast, under these conditions, nif $A p:$ : lac $Z$ expression showed little derepression in the homologous background $(2600 \pm 375$ Miller Units).

To test if activation could occur in heterologous bacteroids, we studied nif $A p:$ : lac $Z$ and fixKp:: lac $Z$ expression in symbiotic conditions. Surprisingly, although it failed to show microaerobic induction, levels of expression comparable to that of symbiotic $\mathrm{R}$. meliloti could be measured from $R$. tropici bacteroids bearing either nif $A p::$ lac $Z$ or fixKp: : lac $Z$ fusions (Table 2). Furthermore, regulation of the expression from both promoters was stricter for $R$. tropici (34-fold increase from nif $A p$ and 169-fold from fix $K p$ ) than for R. meliloti (about 12-fold highest increase). Other Rbizobium backgrounds did not show this type of activation.

\section{Heterologous expression from both $R$. meliloti nifHp and fixAp in other Rhizobium species}

Both nif $\mathrm{H} p$ and $f i x A p$ promoters are moderately activated by $\mathrm{NtrC}$ in free-living $R$. meliloti, but an $n \operatorname{tr} C$ mutant was not affected in its ability to fix nitrogen in symbiosis (Szeto et al., 1987). Three- to 11 -fold increases in expression from nifH $p$ and $f i x A p$ were observed when the heterologous rhizobia were under conditions of nitrogen starvation
(Table 3). We found that $\beta$-galactosidase activity from each promoter increased approximately proportionately, except in R. leguminosarum bv. phaseoli 8002 where a weak 3-fold increase was found for $\mathrm{pMB} 211$ ( $f \times A p::$ lacZ) compared to a 10-fold increase for pMB210 (nifHp: : lacZ). When glucose was used as the carbon source instead of succinate in the nitrogen-free medium, similar levels of induction were found in the heterologous Rbizobium tested (data not shown).

The behaviour observed for both promoters in every rhizobia was much more varied in microaerobic conditions. In the case of nifHp, R. tropici CIAT899 and R. leguminosarum bv. phaseoli 8002 exposed to low oxygen showed activation equivalent to that seen in $R$. meliloti. The initial oxygen concentration for maximal nifH $\mathrm{H}:$ : lac $Z$ microaerobic induction was about $0.75 \% \mathrm{O}_{2}$ for $\mathrm{R}$. meliloti, $0 \cdot 5 \%$ for $R$. tropici and $1 \cdot 25-2 \%$ for $R$. leguminosarum bv. phaseoli (data not shown). For fix $A p$, some increase of microaerobic $\beta$-galactosidase expression could be detected in both $\mathrm{R}$. tropici (6-fold) and R. leguminosarum bv. phaseoli 8002 (3-fold). However, neither nifHp nor fix $A p$ were activated by microaerobic conditions in the other heterologous Rbizobium backgrounds.

As previously reported (Better et al., 1985; Ditta et al., 1987), there was strong induction of expression from both R. meliloti nifH $p$ and $f i x A p$ during symbiosis. Although both microaerobic and symbiotic activation of those promoters was NifA-dependent (Ditta et al., 1987), and R. meliloti expression from nif $A p$ seemed to occur at similar levels in both conditions (Table 2), $\beta$-galactosidase levels from alfalfa bacteroids were at least 4 -fold and 40 -fold greater than those obtained in microaerobiosis from nifHp and fix $A p$, respectively (Table 3). Symbiotic $\beta$ galactosidase expression from $R$. tropici and $R$. leguminosarum bv. phaseoli bearing either nifHp::lacZ or fix $A p$ : : lac $Z$ fusions was also several-fold greater under microaerobic conditions. Differences between symbiotic and microaerobic expression were also much greater in the case of fix $A p:$ : lac $Z$. Clear activation of expression in 
Table 3. Free-living expression of $\beta$-galactosidase by nifHp::lacZ and fixAp::lacZ in different Rhizobium backgrounds

Data are the mean of at least two independent assays $\pm \mathrm{SD} .+\mathrm{N}+\mathrm{O}$, Aerobic cultures in $\mathrm{TY}$ medium; $-\mathrm{N}+\mathrm{O}$, aerobic cultures in nitrogen-free medium; $+\mathrm{N}-\mathrm{O}$, microaerobic cultures in TY medium. ND, Not determined.

\begin{tabular}{|c|c|c|c|c|c|c|c|c|}
\hline \multirow[t]{3}{*}{ Species } & \multicolumn{8}{|c|}{$\beta$-Galactosidase expression (Miller Units) } \\
\hline & \multicolumn{4}{|c|}{$n i f H p:: l a c Z$} & \multicolumn{4}{|c|}{$f i x A p:: l a c Z$} \\
\hline & $+\mathbf{N}+\mathbf{O}$ & $-\mathbf{N}+\mathbf{O}$ & $+\mathbf{N}-\mathbf{O}$ & Symbiotic & $+\mathbf{N}+\mathbf{O}$ & $-\mathbf{N}+\mathbf{O}$ & $+\mathbf{N}-\mathbf{O}$ & Symbiotic \\
\hline R. meliloti & $36 \pm 6$ & $365 \pm 69$ & $1130 \pm 147$ & $4985 \pm 1863$ & $20 \pm 4$ & $161 \pm 33$ & $89 \pm 22$ & $3673 \pm 1783$ \\
\hline R. tropici & $32 \pm 4$ & $210 \pm 47$ & $1590 \pm 374$ & $4451 \pm 870$ & $14 \pm 2$ & $81 \pm 28$ & $64 \pm 14$ & $770 \pm 146$ \\
\hline R. leguminosarum bv, phaseoli & $36 \pm 8$ & $378 \pm 35$ & $974 \pm 106$ & $3072 \pm 43$ & $46 \pm 3$ & $132 \pm 11$ & $154 \pm 45$ & $513 \pm 10$ \\
\hline R. Leguminosarum bv. trifolii & $42 \pm 6$ & $257 \pm 6$ & $36 \pm 1$ & $419 \pm 35$ & $24 \pm 2$ & $147 \pm 10$ & $24 \pm 3$ & $121 \pm 34$ \\
\hline R. leguminosarum bv. viciae & $30 \pm 5$ & $308 \pm 28$ & $25 \pm 2$ & ND & $14 \pm 2$ & $174 \pm 33$ & $12 \pm 2$ & $648 \pm 100$ \\
\hline R. sp. NGR234 & $45 \pm 5$ & $182 \pm 56$ & $25 \pm 10$ & $5062 \pm 58$ & $22 \pm 3$ & $81 \pm 23$ & $21 \pm 2$ & $1547 \pm 48$ \\
\hline R. fredii & $33 \pm 5$ & $273 \pm 46$ & $20 \pm 2$ & $2585 \pm 635$ & $20 \pm 5$ & $169 \pm 14$ & $12 \pm 5$ & $363 \pm 63$ \\
\hline
\end{tabular}

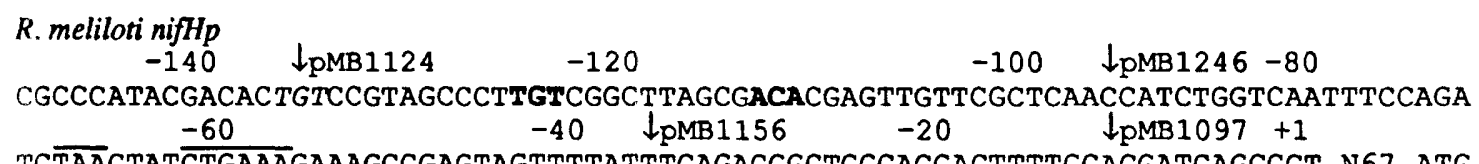

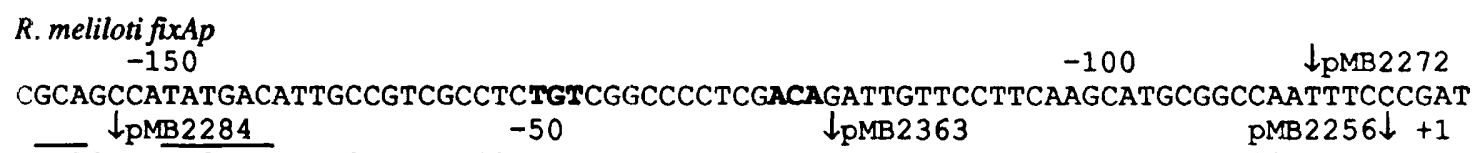

CTAACTATTTGAAAGAAAGCAATTAGCATTATTTCAGTCACCTCTGCGACCTGGCACGACTTTTGCACGATCATCCCC . N120 . ATG

\begin{abstract}
Fig. 1. Sequence of the upstream region of nifHp and fixAp promoters (from Better et al., 1983). Minimal formulations of $\sigma^{54}$ consensus sequences are underlined. Sequences complementary and reverse to the IHF binding consensus described by Hoover et al. (1990) are overlined. Consensus upstream activator sequences are in bold. The TGT motif of nifHp whose deletion may affect NifA-dependent expression is in italics and placed 10 bases upstream from the TGT- $\mathrm{N}_{10}$-ACA motif. Names of deletion plasmids are presented adjacent to the arrow showing each deletion end point. Only deletions that may affect promoter activity are shown.
\end{abstract}

symbiosis was found from both promoters in all the rhizobia studied. Absolute values of $\beta$-galactosidase expression found from nifHp in the heterologous $\mathrm{R} b i$ zobium were similar to that of $R$. meliloti. However, heterologous activation in $\mathrm{R}$. leguminosarum bv. trifolii was at least 6-fold weaker than that obtained in the other backgrounds. Although also showing clear induction in every symbiotic background, absolute $\beta$-galactosidase levels from fix $A p$ : : lac $Z$ were from $2 \cdot 5$-fold (R bizobium sp. NGR234) to 31 -fold (R. leguminosarum bv. trifolii) lower in heterologous bacteroids than in $\mathrm{R}$. meliloti.

\section{Deletion analysis of nifHp and fixAp functions}

Transcription regulatory elements interact with promoters during transcription activation. To determine which regions of the nifHp and fix $A p$ promoters are required for heterologous activation, two series of deletion plasmids extending from the $5^{\prime}$ end of the nifH and fix $A$ promoters were employed. The DNA sequence of these promoters is shown in Fig. 1. At least three regions may be involved in the activity of these promoters: the $\sigma^{54}$ recognition sequences located between -28 and -10 of each promoter (Better et al., 1983); a potential IHFbinding site between -75 and -46 in the case of nifH $\mathrm{H}$ (Hoover et al., 1990), and -80 and -56 in fix $A p$; and an upstream activator sequence (UAS) originally characterized as a highly conserved TGT-N 10 ACA (Buck et al., 1988) NifA binding site (Morett \& Buck, 1988).

In $R$. meliloti, nitrogen-starved activation only required the $-24 /-12$ consensus sequences for promoter activation of each promoter (Figs $2 \mathrm{a}$ and $3 \mathrm{a}$ ). Similar results were obtained when heterologous expression was examined under nitrogen starvation conditions. Therefore, induction of $\beta$-galactosidase expression in every genetic background tested under these conditions did not need other regulatory elements upstream of the $\sigma^{54}$ promoter recognition sequence.

In contrast to nitrogen starvation, more than $85 \%$ of 

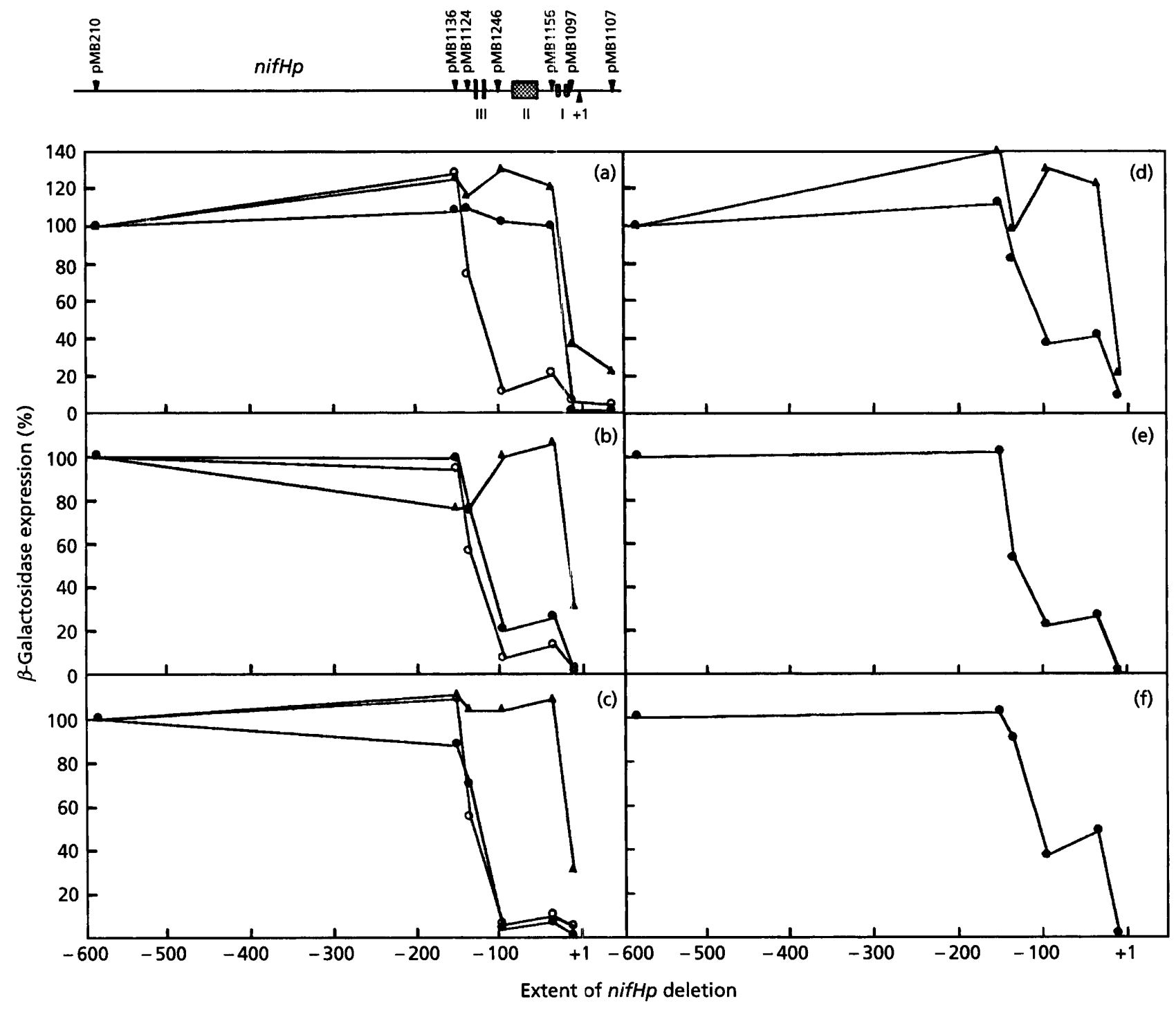

Fig. 2. Homologous and heterologous $\beta$-galactosidase expression from nifHp deletions under nitrogen starvation ( $\mathbf{\Delta}$ ), microaerobic $(O)$ and symbiotic (O) conditions. Results are plotted as the percentage $\beta$-galactosidase activity from pMB210, showing relative expression from nifHp deletion plasmids. (a) $R$. meliloti, (b) $R$. tropici, (c) $R$. leguminosarum bv. phaseoli, (d) R. leguminosarum bv. trifolii, (e) R. fredii and (f) Rhizobium sp. NGR234. Absolute values corresponding to $100 \% \beta$-galactosidase activity for every case are shown in Table 3 . A small scheme of the promoter is presented in the upper left of the figure to facilitate identification of the deletion end points. I, RpoN consensus; II, IHF binding consensus; III, UAS.

nif $\mathrm{H} p$ activity during microaerobiosis was lost when only the UAS was deleted (pMB1246) in both homologous and heterologous backgrounds ( $R$. tropici and $R$. leguminosarum bv. phaseoli) (Fig. $2 \mathrm{a}-\mathrm{c}$ ). Thus, the UAS was required for full nifHp microaerobic activation. Activation was not affected by the nif $\mathrm{H} p$ deletion extending to -95 (pMB1246), nor by a deletion extending to -35 (pMB1156), indicating that when the UAS was deleted, the potential integration host factor (IHF) binding site did not seem to affect positively microaerobic expression. A moderate $(40-50 \%)$ reduction of expression under low oxygen conditions was observed for the three genetic backgrounds containing pMB1124 (deletion to -135).
Furthermore, something of a decrease of expression was observed for every heterologous strain bearing pMB1124 during symbiotic conditions (Fig. 2b-f). Since this plasmid contains an intact UAS (Fig. 1), removal of sequences upstream of this motif negatively affected expression from nifHp.

As previous work in R. meliloti suggested (Better et al., 1985; Ditta et al., 1988), only the $-24 /-12$ region of both promoters was indispensable for complete induction of $\beta$-galactosidase expression during symbiosis. When we observed heterologous symbiotic expression from nifHp deletions (Fig. 2), the patterns were usually comparable to 

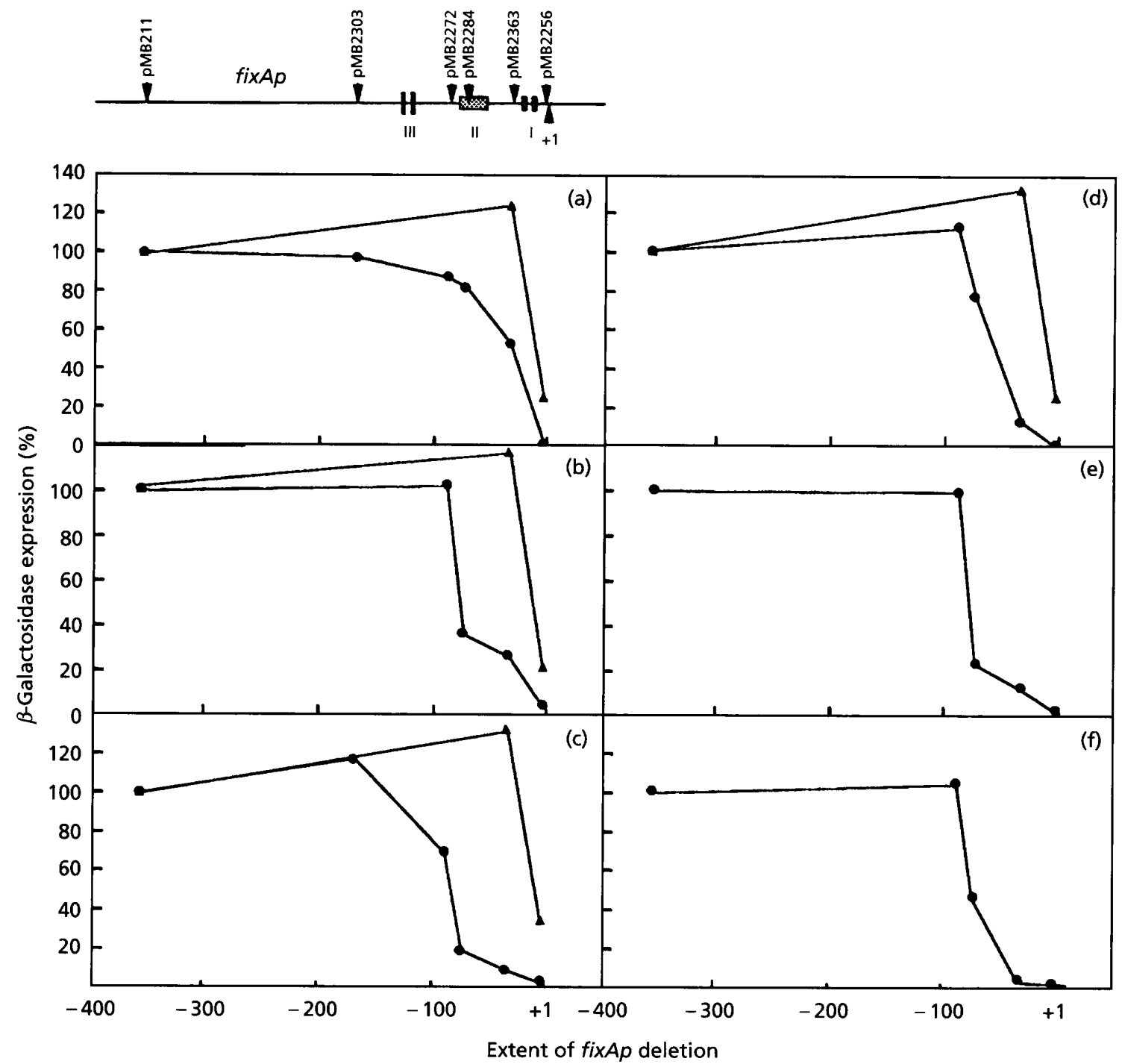

Fig. 3. Homologous and heterologous $\beta$-galactosidase expression from fixAp deletions under nitrogen starvation ( $\mathbf{A}$ ) and symbiotic (O) conditions. Results are plotted as the percentage $\beta$-galactosidase activity from pMB211, showing relative expression from fixAp deletion plasmids. (a) $R$. meliloti, (b) $R$. tropici, (c) $R$. leguminosarum bv. phaseoli, (d) $R$. leguminosarum bv. trifolii, (e) R. fredii and (f) Rhizobium sp. NGR234. Absolute values corresponding to $100 \% \beta$ galactosidase activity for every case are shown in Table 3. A small scheme of the promoter is presented in the upper left of the figure to facilitate identification of the deletion end points. I, RpoN consensus; II, IHF binding consensus; III, UAS.

that of microaerobic $R$. meliloti. Thus, as seen with $R$. meliloti under low oxygen, a $10-50 \%$ loss of nifHp activity was observed in the heterologous Rhizobium bearing pMB1124 under symbiotic conditions (Fig. 2b-f). When the UAS was deleted (pMB1246), $\beta$-galactosidase activity decreased about $50-80 \%$ in the heterologous bacteroids. In R. leguminosarum bv. phaseoli, UAS deletion was most drastic (loss of $95 \%$ activity, Fig. 2c). On the other hand, as seen in microaerobic R. meliloti, the heterologous rhizobia containing pMB1246 (deletion to -95) never showed higher values than when they contained pMB1156 (deletion to -35), during either microaerobic or symbiotic conditions. Therefore, when the UAS was deleted the supposed IHF-binding sequence did not seem to affect promoter activity either in microaerobic or symbiotic conditions.

In contrast, a moderate (approx. 50\%) loss of $\beta$ galactosidase expression in $\mathrm{R}$. meliloti during symbiosis was observed when fix $A p$ was deleted upstream of the $\sigma^{54}$ recognition sequence (Fig. 3a). The same extent of deletion resulted in an even more drastic loss of heterologous symbiotic expression, showing the importance of upstream elements for activation (Fig. 3b-f). Deletion of the $f \times A p$ region up to -88 (pMB2272) had little effect on $\beta$-galactosidase expression during symbiosis. Since the $R$. meliloti fix Ap UAS lies upstream of this deletion endpoint, the UAS sequences may be unnecessary for symbiotic 
fix Ap activation in either the homologous or most of the heterologous backgrounds. Only fix $A p$ activation in R. leguminosarum bv. phaseoli seemed to be slightly affected by the presence of the UAS, showing about $30 \%$ loss of expression when the UAS is deleted (Fig. 3c). In contrast, deletion of the $f x A p$ region from -88 (pMB2272) to -72 (pMB2284) resulted in the loss of a great portion of the observable symbiotic stimulation in the heterologous rhizobia, but almost no loss (only $6 \%$ ) in R. meliloti. That loss was considerable $(60-95 \%)$ for most of the genetic backgrounds, but only $25 \%$ for $R$. leguminosarum bv. trifolii. A DNA sequence similar to the IHF-binding site consensus sequence was identified between -77 and -63 of $f i x A p$ (Fig. 1); it was $1 \mathrm{bp}$ closer to the IHF-binding site consensus sequence (A/T)ATCAA- $\mathrm{N}_{4}-\mathrm{TT}(\mathrm{A} / \mathrm{G})$ (Hoover et al., 1990) than the similar sequence seen in nif $\mathrm{H} p$. When this region was completely deleted $(-33$, pMB2363), an additional decrease in heterologous expression was observed. Nevertheless, in most of the cases there was still a residual regulation activity of the promoter some fold higher than the basal level.

\section{DISCUSSION}

Neither R. meliloti nif $A p$ nor $f i x K p$ is activated either in free-living microaerobic or in symbiotic heterologous rhizobia (except in symbiotic R. tropici). This fact makes it difficult to extrapolate the regulatory cascade of $R$. meliloti symbiotic nitrogen fixation (David et al., 1988; Batut et al., 1989) to other Rbizobium species. This cascade starts with the oxygen sensor and kinase FixL which catalyses its own phosphorylation under low oxygen tension (Gilles-Gonzalez et al., 1991). Then, the transcriptional activator Fix $\mathrm{J}$ is also phosphorylated catalysing nif $A p$ and $f x K p$ activity (Batut $e t$ al., 1989; GillesGonzalez et al., 1991; Kahn \& Ditta, 1991). Some genes have been described whose expression is oxygenregulated via a mechanism involving fix $L J$ : a fixK-like gene in A. caulinodans (Kaminski \& Elmerich, 1991), and fixK (Anthamatten et al., 1992) in B. japonicum. Each of these symbiotic bacteria are expected to be genetically more distanced from $R$. meliloti than the species used in this study. It is thus surprising that neither microaerobic nor symbiotic conditions were able to activate transcription from R. meliloti nif $A p$ and $f i x K p$ in most of the heterologous rhizobia. The simplest hypothesis would be that there are no functional homologous fix $L J$ in those strains. This is consistent with the fact that only weak homology has been found between the fix $L J$ region of $R$. meliloti and other Rhizobium species (Ditta et al., 1988), and that no significant hybridization signals could be detected in $R$. leguminosarum bv. viciae (Colonna-Romano et al., 1990). In R. leguminosarum bv. viciae, the fnr $N$ gene, homologous to R. meliloti fix $K$, is capable of promoting microaerobic and symbiotic induction of fix $N$ independently of fixLJ (Colonna-Romano et al., 1990). Alternatively, nif regulation of the heterologous rhizobia tested here may occur via $f \times L J$, but result in production of an inactive FixJ or one without affinity for the R. meliloti nif $A p$ and $f x K p$ used in this study. In $A$. caulinodans, while fix $K p$ shows sequence homology to that of $\mathrm{R}$. meliloti,
NifA expression is activated via FixK. Despite the fact that $A$. caulinodans fix $L J$ are structurally very similar to $R$. meliloti fix $L J, R$. meliloti nif $A p$ ( $\beta$-galactosidase) expression was not significantly induced in microaerobic cultures of A. caulinodans (Kaminski \& Elmerich, 1991). This is consistent with the idea that the presence of fix $L J$ alone in other Rhizobium species may not guarantee microaerobic or symbiotic activation of $\mathrm{R}$. meliloti nif $A p$.

As an exception among the rhizobia tested, it was surprising that $R$. tropici CIA T899 could strongly activate nif $A p$ and $f \times K p$ under symbiotic conditions but not during microaerobiosis. This result suggests the existence of a Fix J-like protein in R. tropici whose activation signal occurs in nodules but not under microaerobic conditions ex planta. Since in vitro low oxygen was not sufficient to induce Fix J-dependent promoters, it may be considered that the regulators that caused its activation (FixLJ in $R$. meliloti) may respond to some other physiological signal in planta. It may also be possible that another factor is needed for Fix J-mediated activation or for activating a Fix J-like protein in $R$. tropici.

Moderate induction from nif $A p$ under nitrogen starvation conditions occurred in both the homologous and heterologous Rhizobium. However, fixKp could not be significantly activated ex planta in all the heterologous backgrounds. Accordingly, Nooman et al. (1992) described that ammonia negatively regulates microaerobic expression of nif $A$ but not of fixK. de Philip et al. (1990) also found differences in FixLJ-mediated regulation of nif $A$ and $f i x K$ genes, at least in $E$. coli. The nature and meaning of these differences remain unknown.

R. meliloti nifH $p$ and $f i x A p$ in the heterologous rhizobia behaved very similarly to when they were in their homologous background, under nitrogen-limiting conditions. The fact that sequences upstream of the $\sigma^{54}$ recognition region are unnecessary for induction of $\beta$ galactosidase expression under nitrogen limitation in the three species tested, indicates that this activation is probably not specific. Activation of both promoters under nitrogen starvation was shown to be dependent on the general nitrogen regulatory protein NtrC in R. meliloti (Szeto et al., 1987). None of our results contradicts the idea that activation of NifA-dependent promoters under free-living nitrogen starvation by $\mathrm{NtrC}$ is conserved among different Rbizobium species.

Rbizobium RpoN/NifA-dependent promoters are extremely well conserved (Alvarez-Morales \& Hennecke, 1985; Better et al., 1983). Even though both R. meliloti promoters were activated to some extent during symbiosis, activation of nifH $p$ and $f x A p$ in microaerobiosis were not observed in several Rhizobium species. However, microaerobic activation in both $R$. tropici and $R$. leguminosarum bv. phaseoli was very similar to that seen in the homologous background. These rhizobia that activate both promoters in microaerobic conditions may produce an active NifA ex planta. On the other hand, Rbizobium backgrounds that failed to induce expression in low oxygen may not have an active NifA, or may need other 
factors, found in bacteroids, to achieve activation by NifA. Alternatively, a repression could be exerted $e x$ planta to prevent free-living expression of nitrogenase. Therefore, the use of in vitro microaerobic conditions as a model system for studies on the mechanisms of $f i x$ regulation using heterologous promoters may be limited in many Rbizobium species.

In contrast to $R$. meliloti, the heterologous Rhizobium required more than the $-24 /-12$ consensus sequence of $n i f H p$ and $f i x A p$ to achieve full symbiotic transcriptional activation. Almost all expression is lost when the NifAbinding sequences are deleted from nifH $p$. Microaerobic activation of nifHp required the same DNA segments in R. meliloti, R. tropici and R. leguminosarum bv. phaseoli. Furthermore, these DNA segments coincide with those required for heterologous expression during symbiosis. Heterologous microaerobic and symbiotic activation of nif $\mathrm{H} p$ seemed to be highly dependent on the UAS, suggesting activation by NifA. On the other hand, deletion analysis of $\mathrm{R}$. meliloti nifH $\mathrm{H}$ suggests an alternative UAS as a TGT-N ${ }_{10}-$ TGT-N $_{10}$-ACA motif (Fig. 1). Since the minimal UAS consensus, described as a TGT$\mathrm{N}_{10}$-ACA motif, remained intact in pMB1124 (-135), and alteration of the first repeated TGT resulted in a loss of promoter activation during both microaerobiosis and symbiosis in the heterologous Rhizobium, this suggests that this sequence contributed to NifA-nifH $p$ affinity.

NifA activation of nif promoters that lack a NifA binding site could be accomplished if there is a high concentration of active NifA and appropriate RNA polymerase recognition sequences (Albright et al., 1988; Buck \& Cannon, 1989). One might expect that the level and/or the activity of $R$. meliloti NifA in mature nodules is higher than exists either in microaerobic conditions or in the heterologous Rbizobium bacteroids. This expectation is compatible with the results with fix Ap in $\mathrm{R}$. meliloti. Deletion analysis of this promoter indicated that the UAS was not necessary for full heterologous activation in symbiotic rhizobia. Consistent with these results is the finding that the $B$. japonicum fix $A$ promoter has no UAS of the TGT- $\mathrm{N}_{10}$-ACA type, yet its expression is also strongly dependent on the presence of NifA (Gubler \& Hennecke, 1988; Gubler, 1989). Surprisingly, although activation was UAS-independent, a sequence identified as a potential IHF binding site, seemed to be necessary for most $R$. meliloti fix $A$ heterologous expression. IHF has the ability to bend DNA significantly (Friedman, 1988). The model of IHF function in $\sigma^{54}$-dependent promoters proposed for $K$. pneumoniae nif $H p$ (Hoover $e t$ al., 1990), corroborated for the promoters $P s$ of $x y l S, P u$ of $x y l C A B$ (Holtel et al., 1990 ; de Lorenzo et al., 1991) and $g \ln H p$ (Claverie-Martín \& Magasanik, 1991), is that it helps to achieve both high efficiency and high fidelity in the control of transcription mediated by its particular activators, especially for weak promoters. According to this model, IHF binding could not stimulate transcription independent of the UAS. The behaviour of $f x A p$ could have two possible explanations. Firstly, other as yet uncharacterized sequences potentially essential for activation might have been removed in the deletions that also remove the IHF binding motif.
Secondly, although expression depends on $\sigma^{54}$, it is possible that IHF function at $f i x A p$ differs from that of other $\sigma^{54}$-dependent promoters, because IHF bending of DNA may help to activate fix $A p$ independent of the UAS. Since specific activation of $f i x A p$ under nitrogen starvation was independent of the IHF binding motif, IHF may act as an architectural element in the assembly of a NifA $/ \sigma^{54}$-dependent transcription initiation complex. In this complex, the fix $A p$ UAS could be unnecessary. IHF binding might improve both its efficiency and specificity for symbiotic expression of the fix $A B C X$ operon contributing to its fine-tuning control. Further study of the role and function of Rbizobium IHF in symbiotic expression of nitrogen fixation genes may be required for a fuller elucidation of $f i x$ gene regulation.

This report indicates that there are some common features in the expression of $R$. meliloti symbiotic nitrogen fixation genes (at least those controlled by NifA) that are shared by heterologous Rbizobium species. We also present evidence that the control mechanisms may differ to some extent among the Rbizobium species. Other bacteria with a similar life style, B. japonicum and $A$. caulinodans, differ considerably in their $f x$ regulation circuits but share many of the known regulatory elements (FixL, FixJ, FixK, NifA, nif-promoters, etc). There is specificity in the Rhizobium-legume interaction; some Rbizobium genes are adapted for nodulation of a specific plant (e.g. nod specificity genes, nodD-flavonoid specificity, exo genes; see reviews of Long, 1989; and Martínez et al., 1990). It is likely that such parameters as nodule development and the physiological conditions specific to a particular plant, vary in other plants. Because of that, each specific Rbizobium has probably optimized nitrogen fixation during the course of evolution, adapting its regulatory mechanisms to fit the host plant conditions, resulting in diversification of Rbizobium symbiotic fix regulation circuits.

\section{ACKNOWLEDGEMENTS}

We thank Gary Ditta for providing most of the plasmids. We also thank Dr Boistard for providing pJJ5 plasmid, Dr E. Santero for his valuable comments and criticism, Dr D. N. Rodríguez and Dr F. Temprano for their help in plant tests. A.C. was an FPI fellowship recipient. Research support from the Spanish Ministry of Education and Science through CYCYT projects PB87-0918 and BIO90-0521, and from Fundación Ramón Areces is gratefully acknowledged.

\section{REFERENCES}

Agron, P., Ditta, G. \& Helinski, D. R. (1992). Mutational analysis of the Rbizobium meliloti nif $A$ promoter. J Bacteriol 174, 4120-4129.

Albright, L. M., Huala, E., Gu, Q. \& Ausubel, F. E. (1988). Regulation of $R$. meliloti NifA function. In Nitrogen Fixation: Hundred Years After, pp. 345-349. Edited by H. Bothe, F. J. de Bruijn \& W. E. Newton. Stuttgart: Gustav Fischer.

Alvarez-Morales, A. \& Hennecke, H. (1985). Expression of Rbizobium japonicum nif $H$ and nifD $K$ operons can be activated by the Klebsiella pneumoniae nif $A$ protein but not by the product of $n \operatorname{tr} C$. Mol \& Gen Genet 199, 306-314. 
Anthamatten, D. \& Hennecke, H. (1991). The regulatory status of the $f x L$ and $f i x J$ genes in Bradyrbizobium japonicum may be different from that in Rbizobium meliloti. Mol \& Gen Genet 225, 38-48.

Anthamatten, D., Scherb, B. \& Hennecke, H. (1992). Characterization of a fix $L J$-regulated Bradyrbizobium japonicum gene sharing similarity with the Escherichia coli fnr and Rbizobium meliloti fixK genes. J Bacteriol 174, 2111-2120.

Batut, J., Daveran, M. L., David, M., Jacobs, J., Garnerone, A. M. \& Kahn, D. (1989). fix $K$, a gene homologous with $f n r$ and $c r p$ from Escherichia coli, regulates nitrogen fixation genes both positively and negatively in Rhizobium meliloti. EMBO J 8, 1279-1286.

Batut, J., Santero, E. \& Kustu, S. (1991). In vitro activity of the nitrogen fixation regulatory protein Fix J from Rbizobium meliloti. J Bacteriol 173, 5914-5917.

Better, M., Lewis, B., Corbin, D., Ditta, G. \& Helinski, D. R. (1983). Structural relationships among Rbiqobium meliloti symbiotic promoters. Cell 35, 379-385.

Better, M., Ditta, G. \& Helinski, D. R. (1985). Deletion analysis of Rbizobium meliloti symbiotic promoters. EMBO J 4, 2419-2424.

Birkenhead, K., Nooman, B., Reville, W. J., Boesten, B., Manian, S. S. \& O'Gara, F. (1990). Carbon utilization and regulation of nitrogen fixation genes in Rbizobium meliloti. Mol Plant-Microbe Interact 3, 167-173

Boyer, H. W. \& Roulland-Dussoix, D. (1969). A complementation analysis of restriction and modification in Escherichia coli. J Mol Biol 41, 459-472.

Buck, M. \& Cannon, W. (1989). Mutation in the RNA polymerase recognition sequence of Klebsiella pneumoniae nifH promoter permitting transcriptional activation in the absence of NifA binding to upstream activator sequences. Nucleic Acids Res 17, 2597-2612.

Buck, M., Miller, S., Drummond, M. \& Dixon, R. (1988). Upstream activator sequences are present in the promoters of nitrogen fixation genes. Nature 320, 374-378.

Claverie-Martín, F. \& Magasanik, B. (1991). Role of integration host factor in the regulation of the $g \ln \mathrm{H} p 2$ promoter of Escherichia coli. Proc Natl Acad Sci US A 88, 1631-1635.

Colonna-Romano, S., Arnold, W., Schluter, A., Boistard, P., Puhler, A. \& Preifer, U. B. (1990). An Fnr-like protein encoded in Rbizobium leguminosarum biovar viciae shows structural and functional homology to Rbizobium meliloti FixK. Mol \& Gen Genet 223, 138-147.

Corbin, D., Barran, L. \& Ditta, G. (1983). Organization and expression of Rbizobium meliloti nitrogen fixation genes. Proc Natl Acad Sci US A 80, 3005-3009.

David, M., Daveran, M. L., Batut, J., Declien, A., Domergue, O., Ghai, J., Hertig, C., Boistard, P. \& Kahn, D. (1988). Cascade regulation of nif gene expression in Rbizobium meliloti. Cell 54, 671-683.

Ditta, G., Stanfield, S., Corbin, D. \& Helinski, D. R. (1980). Broad host range DNA cloning system for Gram-negative bacteria: construction of a gene bank of Rhizobium meliloti. Proc Natl Acad Sci US A 77, 7347-7351.

Ditta, G., Schmidhauser, T., Yakobson, E., Lu, P., Liang, X.-W., Finlay, D. R., Guiney, D. \& Helinski, D. R. (1985). Plasmids related to the broad host range vector, pRK290, useful for gene cloning and for monitoring gene expression. Plasmid 13, 149-153.

Ditta, G., Virts, E., Palomares, A. \& Kim, C. K. (1987). The nif $A$ gene of Rhizobium meliloti is oxygen regulated. J Bacteriol 169, $3217-3223$

Ditta, G., Virts, E. \& Helinski, D. R. (1988). Oxygen regulation of nif genes in Rbizobium meliloti. In Molecular Genetics of Plant-Microbe Interactions, pp. 109-110. Edited by D. P. S. Verma \& R. Palacios. Saint Paul, MN : APS Press.
Dowdle, S. F. \& Bohlool, B. B. (1985). Predominance of fastgrowing Rbizobium japonicum in a soybean field in the People's Republic of China. Appl Environ Microbiol 50, 1171-1176.

Fisher, H. M. \& Hennecke, H. (1987). Direct response of Bradyrbizobium japonicum nif $A$-mediated nif gene regulation to cellular oxygen status. Mol \& Gen Genet 209, 621-626.

Fisher, H. M., Bruderer, T. \& Hennecke, H. (1988). Essential and non-essential domains in the Bradyrbizobium japonicum NifA protein: identification of indispensable cysteine residues potentially involved in redox reactivity and/or metal binding. Nucleic Acids Res 16, 2207-2224.

Friedman, D. I. (1988). Integration host factor: a protein for all reasons. Cell 55, 545-554.

Gilles-Gonzalez, M. A., Ditta, G. \& Helinski, D. R. (1991). A haemoprotein with quinase activity encoded by the oxygen sensor of Rbizobium meliloti. Nature 350, 170-172.

Gubler, M. (1989). Fine-tuning of nif and $f i x$ gene expression by upstream activator sequences in Bradyrbizobium japonicum. Mol Microbiol 3, 149-159.

Gubler, M. \& Hennecke, H. (1988). Regulation of the fix $A$ gene and fix BC operon in Bradyrbizobium japonicum. J Bacteriol 170, 1205-1214.

Holtel, H., Abril, M.-A., Marques, S., Timmis, K. N. \& Ramos, J. L. (1990). Promoter-upstream activator sequences are required for expression of the $x y l S$ gene and upper-pathway operon on the Pseudomonas TOL plasmid. Mol Microbiol 4, 1551-1556.

Hoover, T. R., Santero, E., Porter, S. \& Kustu, S. (1990). The Integration Host Factor (IHF) stimulates interaction of RNA polymerase with NifA, the transcriptional activator for nitrogen fixation operons. Cell 63, 11-22.

Johnston, A. W. B. \& Beringer, J. E. (1975). Identification of the Rbizobium strains in pea root nodule using genetic markers. $J \mathrm{Gen}$ Microbiol 87, 343-350.

Kahn, D. \& Ditta, G. (1991). Modular structure of Fix J : homology of the transcriptional activator domain with the -35 binding domain of sigma factors. Mol Microbiol 5, 987-997.

Kaminski, P. A. \& Elmerich, C. (1991). Involvement of fixLJ in the regulation of nitrogen fixation in Azorbizobium caulinodans. Mol Microbiol 5, 665-673.

Kaminski, P. A., Mandon, K., Arigoni, F., Desnoues, N. \& Elmerich, C. (1991). Regulation of nitrogen fixation in Azorbizobium caulinodans: identification of a fixK-like gene, a positive regulator of nif $A$. Mol Microbiol 5, 1983-1991.

Kustu, S., Santero, E., Keener, J., Popham, D. \& Weiss, D. (1989). Expression of the $\sigma^{54}(n \operatorname{tr} A)$-dependent genes is probably united by a common mechanism. Microbiol Rev 53, 367-376.

Lamb, J. M., Hombrecher, G. \& Johnston, A. W. B. (1982). Plasmid determined nodulation and nitrogen fixation abilities in Rbizobium phaseoli. Mol \& Gen Genet 186, 449-452.

Long, S. (1989). Rbizobium-legume nodulation: life together in the underground. Cell 56, 203-214.

de Lorenzo, V., Herrero, M., Metzke, M. \& Timmis, K. N. (1991). An upstream XylR- and IHF-induced nucleoprotein complex regulates the $\sigma^{54}$-dependent $\mathrm{Pu}$ promoter of TOL plasmid. EMBO $J$ 10, 1159-1167.

Martínez, E., Romero, D. \& Palacios, R. (1990). Rbizobium genome. Crit Rev Plant Sci 9, 59-87.

Martinez-Romero, E., Segovia, L., Mercante, F. M., Franco, A. A., Graham, P. \& Pardo, M. A. (1991). Rbizobium tropici, a novel species nodulating Phaseolus vulgaris $\mathrm{L}$. beans and Leucaena sp. trees. Int $J$ Syst Bacteriol 41, 417-426.

Meglas, M., Caviedes, M. A., Andres, M., Sousa, C., Ruiz- 
Berraquero, F. \& Palomares, A. J. (1989). Localization of bis genes on the Rbizobium trifolii RS800 linkage map. Mol \& Gen Genet 211, 369-372.

Miller, J. H. (1972). Experiments in Molecular Genetics. Cold Spring Harbor, NY: Cold Spring Harbor Laboratory.

Morett, E. \& Buck, M. (1988). NifA-dependent in vivo protection demonstrated that the upstream activator sequence of nif promoter is a protein binding site. Proc Natl Acad Sci US A 85, 9401-9405.

Nooman, B., Motherway, M. \& O'Gara, F. (1992). Ammonia regulation of the Rbizobium meliloti nitrogenase structural and regulatory genes under free-living conditions: involvement of the fix L gene product? Mol \& Gen Genet 234, 423-428.

de Philip, P., Batut, J. \& Boistard, P. (1990). Rhizobium meliloti FixL is an oxygen sensor and regulates $R$. meliloti nif $A$ and $f i x K$ genes differently in Escherichia coli. J Bacteriol 172, 4255-4262.

Ratet, P., Pawloski, K., Schell, J. \& de Bruijn, F. J. (1989). The Azorbizobium caulinodans nitrogen fixation regulatory gene, nif $A$, is controlled by the cellular nitrogen and oxygen status. Mol Microbiol 3, 825-838.

Ronson, C. W., Nixon, B. T., Albright, L. M. \& Ausubel, F. M. (1987). Rbizobium meliloti ntr $A$ (rpoN) gene is required for diverse metabolic functions. $J$ Bacteriol 169, 2424-2431.

Ruvkun, G. B., Sundaresan, V. \& Ausubel, F. M. (1982). Directed transposon Tn 5 mutagenesis and complementation analysis of Rbizobium meliloti and related bacteria. Cell 29, 551-559.

Santero, E., Keener, J. \& Kustu, S. (1989). In vitro activity of the nitrogen fixation regulatory protein NIFA. Proc Natl Acad Sci US A 88, 7346-7350.

Szeto, W. W., Zimmerman, J. L., Sundaresan, V. \& Ausubel, F. M.
(1984). A Rhizobium meliloti symbiotic regulatory gene. Cell 36, 1035-1043.

Szeto, W. W., Nixon, B. T., Ronson, C. W. \& Ausubel, F. M. (1987). Identification and characterization of the Rbizobium meliloti ntrC gene: $R$. meliloti has separate regulatory pathways for activation of nitrogen genes in free-living and symbiotic cells. J Bacteriol 169, 1423-1432.

Thöny, B. \& Hennecke, H. (1989). The $24 / 12$ promoter comes from ages. FEMS Microbiol Rev 63, 341-358.

Thøny, B., Fischer, H.-M., Anthamatten, D., Bruderer, T. \& Hennecke, H. (1987). The symbiotic nitrogen fixation regulatory operon ( $f x \mathrm{Rnif} A$ ) of Bradyrbizobium japonicum is expressed aerobically and is subject to a novel, nif $A$-independent type of activation. Nucleic Acids Res 15, 8479-8499.

Trinick, M. J. (1980). Relationships amongst the fast-growing rhizobia of Lablab purpureus, Leucaena leucocepbala, Mimosa spp., Acacia farnesiana and Sesbania glandiflora and their affinities with other rhizobial groups. J Appl Bacteriol 49, 39-53.

Virts, E. L., Stanfield, S. W., Helinski, D. R. \& Ditta, G. (1988). Common regulatory elements control symbiotic and microaerobic induction of nif $A$ in Rbizobium meliloti. Proc Natl Acad Sci US A 85, 3062-3065.

Waelkens, F., Foglia, A., Morel, J.-B., Fourment, J., Batut, J. \& Boistard, P. (1992). Molecular genetic analysis of the Rbizobium meliloti fix $K$ promoter: identification of sequences involved in positive and negative regulation. Mol Microbiol 6, 1447-1456.

Received 21 May 1993; revised 17 September 1993; accepted 6 October 1993. 